disinhibition; that this effect is temporary and dissipates with time; that ECS either neutralizes the emotional response which causes the PRE or interferes with the previously established connection between the emotional response and the stimuli of the experimental environment.

Regardless of interpretation, however, these findings do not support the hypothesis that memory consolidates over time and that the effect of ECS is the disruption of a memory trace that is in the process of becoming permanently fixed.

REFERENCES
AMSEL, A. The role of frustrative
nonreward in noncontinuous reward
situations. Psychological Bulletin, 1958,
$55,102-119$.
CHEVALIER, J. A. Permanence of amnesia
after a single post-trial electroconvulsive
seizure. Joumal of Comparative \&
Physiological Psychology, 1965, 59 ,
$73-78$.
COOPER, R. M., \& KOPPENAAL, R. J.
Suppression and recovery of a one-trial
avoidance response after a single ECS.
Psychonomic Science, 1964, 1 , 303-304.
GREENOUGH, W. T., SCHWITZGEBEL, R.
L. \& FULCHER, J. K. Permanence of
ECS-produced amnesia as a function of
test conditions. Journal of Comparative \&

Physiological Psychology, 1968, 66. 554-556.

KOHLENBERG, R., \& TRABASSO, T Recovery of a conditioned emotional response after one or two electroconvulsive shocks. Joumal of Comparative \& Physiological Psychology $1968,65,270-273$

LEWIS, D.J. Sources of experimental amnesia. Psychological Reveiw, 1969, 76 , 461-472.

McGAUGH, J. L. Time-dependent processe in memory storage. Science, $1966,153$. $1351-1358$.

MILLER, A. J, Variations in retrograde amnesia with parameters of electroconvulsive shock and time of testing. Journal of Comparative \& Physiological Psychology, 1968, 66, 40-47.

SPEVACK, A. A., \& SUBOSKI, M. D Retrograde effects of electroconvulsive shock on learned responses. Psychological Bulletin, 1969, 72, 66-76.

YOUNG, A. G., \& GALLUSCIO, E. H. Failure of ECS to produce retrograde amnesia following partial reinforcement training. Psychonomic Science, 1970a, $18,175-176$.

YOUNG, A. G., \& GALLUSCIO, E. H. Effect of EĆs on one-trial learning following continuous and partial reinforcement training. Psychonomic Seience, $1970 \mathrm{~b}, 21,43-44$.

YOUNG, A. G., \& DÁY. H. D. ECS effects following continous and partial reinforcement training. Psychonomic Science, 1970, 21, 130-131.

\title{
The effect of hyperbaric oxygen on memory*
}

\author{
JERRY D. ERKERT and CHARLES J. VIERCK, JR. \\ University of Florida, Gainesville, Fla. 32601
}

The effect of oxygen at high pressure (OHP) on memory was investigated. Multiple exposures to OHP after training in a Lashley III maze produced significant retention deficits, confirming a previous study. However, exposures to OHP failed to produce retention deficits of a T-maze position habit. The results suggest that the Lashley III maze deficit was produced by alterations in activation and not by a memory deficiency.

That oxygen at high pressure (OHP) causes oxygen toxicity resulting in convulsions of the grand mal type has been known since the classical work of Bert in 1878. Subsequent research has demonstrated that cellular metabolism, especially that of the central nervous system, is markedly depressed by exposures to OHP (Dickens, 1946; Haugaard, 1968). The posttrial administration of convulsive

*This research was supported by Grants MH10320 and NS07261 from the United States Public Health Service. We would also like to acknowledge the invaluable assistance of David Desautels, Chief of Inhalation Therapy, Shands Teaching Hospital, University of Florida, in the design of the hyperbaric chamber used in this research. seizures (by electroconvulsive shock) and depression of central nervous system metabolism (by drugs) have been found to be effective in producing retrograde amnesia (Chorover \& Schiller, 1965; McGaugh \& Petrinovitch, 1965). Consequently, it might be expected that OHP would be an effective amnesic agent. Bean and his associates (1943, 1945) have, in fact, reported that daily exposures to OHP after training in a Lashley III maze produced a retention deficit, as measured both by errors and trials to criterion during retraining.

In view of the increasing use of $\mathrm{OHP}$ as a medical therapeutic, elaboration of these findings should be of considerable interest to medical personnel conducting high-pressure oxygen therapy. Furthermore, OHP may be a valuable new tool in the study of memory through amnesia, especially when used with those drugs known to retard the different manifestations of oxygen toxicity (Johnson \& Bean, 1954; Taylor, 1956; Wood et al, 1967). The first study reported here is a replication of Bean's earlier observation, and the second tests the generality of the retention deficit.

\section{APPARATUS}

A small animal pressure chamber, approximately $23 \mathrm{in}$. long and $15 \mathrm{in}$. in diam and with a Plexiglas window for observation, was used for the oxygen exposure. The chamber contained a small cage for restraining the animal and two packages of baralyme to aid in the control of the $\mathrm{CO}_{2}$ level in the chamber. Pressurizing the chamber with oxygen was accomplished by means of a high-pressure oxygen cylinder and regulator.

\section{EXPERIMENT 1}

In a replication of Bean's earlier work, six adult rats (Wistar) were placed on a 23-h food-deprivation schedule and maintained at $80 \%$ of their original weight. Each $\mathbf{S}$ was given one $75-\mathrm{mg}$ Noyes food pellet in the goalbox of a Lashley III maze (1964) before regular feeding once a day for 6 days prior to training. All animals were trained to a criterion of 9 out of 10 errorless trials with retracing errors prevented by guillotine doors. Trials were presented in blocks of 15 per day, except for the first and second days of training, on which the animals received 5 and 10 trials, respectively. The order in which the animals were trained was reversed from day to day. The experimental and control groups were matched in terms of the number of errors required to learn the maze.

Twenty-four hours after the last training session, the experimental animals received $O H P$ twice a day for 10 days. The animals were sealed one at a time into the chamber, which was then flushed for $3 \mathrm{~min}$ with oxygen at a flow rate of 50 to $65 \mathrm{liters} / \mathrm{min}$. The pressure inside the chamber was raised to 60 psig over a $4-\mathrm{min}$ period (1 at $/ \mathrm{min}$ ). The $\mathrm{S}$ remained at pressure for $15 \mathrm{~min}$ or until it showed signs of convulsions (twitching), whichever came first. The ventilatory flow rate of the chamber during this period was approximately 40 liters/min. Gas analysis of the chamber at the end of the 15 -min period at 60 psig was $0.0 \%$ $\mathrm{CO}_{2}, 0.8 \% \mathrm{~N}_{2}$, and $99.2 \% \mathrm{O}_{2}$ at $25^{\circ} \mathrm{C}$.

Twenty-four hours after the last exposure to OHP, the Ss were retrained in the maze to the original criterion. The control animals were left in their home cages, except for daily weighing, for the 10 days prior to retesting. 
Table 1

The Effects of OHP Upon the Retention of the Lashley III Maze Habit in Rats

\begin{tabular}{cccccc}
\hline $\begin{array}{c}\text { Animal } \\
\text { Number } \\
\text { and Group }\end{array}$ & $\begin{array}{c}\text { Errors to } \\
\text { Criterion }\end{array}$ & $\begin{array}{c}\text { Trials to } \\
\text { Criterion }\end{array}$ & & $\begin{array}{c}\text { Errors to } \\
\text { Criterion }\end{array}$ & $\begin{array}{c}\text { Trials to } \\
\text { Criterion }\end{array}$ \\
\hline $\begin{array}{c}\text { Experimental } \\
\text { A3 }\end{array}$ & & & OHP & 40 & \\
A6 & 35 & 45 & & 24 & 25 \\
A8 & 74 & 60 & 11 & 25 \\
Mean & 79 & 120 & & 25 & 33 \\
Control & 62.7 & 75 & 10 Days & 1 & \\
A4 & & & & 1 & 10 \\
A7 & 28 & 54 & & 2 & 11 \\
A5 & 53 & 71 & 1.3 & 10.3 \\
Mean & 133 & 134 & & & \\
\hline
\end{tabular}

Results

The results of Experiment 1 are summarized in Table 1 and indicate that the retention scores of those animals receiving exposures to $\mathrm{OHP}$ were significantly inferior to those of the control animals. All of the experimental animals displayed the retention deficit, as measured by errors or trials to criterion during relearning $(p>.05)$. Each animal convulsed on the average of four times during the 10 days of oxygen treatment.

\section{Discussion}

Our data agree with those of Bean (1943, 1945). However, the probability that the deficit produced by OHP is a performance phenomenon rather than a disruption of long-term storage is strongly indicated by the observation that all of the experimental animals appeared: (1) to be hyperexcitable during handling and retraining in the maze, (2) to commit overrunning rather than wrong-turn errors, and (3) to remember the habit fairly well, making on the average only one error out of a possible eight on a given run through the maze and frequently running five or six consecutive errorless trials early in the retraining session. Thus, it is possible that increased excitability following OHP exposures led to the higher error scores in the experimental group. One test of this hypothesis is to employ a maze in which overrunning errors are prevented and running speed is not a factor.

\section{EXPERIMENT 2}

Eight adult rats were placed on a feeding schedule and pretrained as above. All animals were then given position training in a T-maze to a criterion of 10 out of 11 errorless trials. The Ss were given 15 trials a day, with half of the Ss being reinforced on each side of the maze. The Ss were then divided into two equal groups matched on the basis of the number of errors made during acquisition. OHP was administered as described earlier, with subsequent retraining in the $\mathrm{T}$-maze to the original criterion.
An alternative explanation, and the one favored here, is that increased excitability following exposures to OHP predisposes the animals to make an occasional error when choice responses follow rapidly in succession, as in the Lashley III maze. In any case, generalized memory disturbance was not obtained with repeated and severe OHP treatments. These results indicate that further studies of the emotionality and activity patterns of treated animals should be of considerable interest.

\section{REFERENCES}

As can be seen in Table 2, there is no significant difference between the retention scores of the two groups. The average number of convulsions during the 10 days of oxygen exposure was four and a half.

\section{DISCUSSION}

The results of Experiment 1 support the position that multiple exposures to hyperbaric oxygen produces a residual change in the rat that manifests itself in the form of increased error scores during retention tests in the Lashley III maze. The results of Experiment 2, on the other hand, indicate that this retention deficit is task specific. It might be argued that a difference in task difficulty could account for this finding; the memory for a simpler task ( $T$-maze) might be less vulnerable to the disruptive effects of OHP than that of a more difficult task (Lashley III maze), as is often the case in lesion studies. However, the T-maze may not necessarily be the easier of the two mazes for a rat to learn. The T-maze lacks the many visual cues found in the Lashley III maze. That the two mazes are approximately equal in difficulty is further indicated by the lack of a significant difference between the number of trials to criterion for the two groups of Ss.
BEAN, J, W \& WAPNER, S, Effects of $\mathrm{OHP}$ on higher functions of the central nervous system. Proceedings of the Society of Experimental Biology \& Medicine, 1943, 54, 134-135.

BEAN, J. W., WAPNER, S., \& SIEGFRIED. $E$. Residual disturbances in the higher functions of the CNS induced by exposure to OHP. American Journal of Physiology, 1945, 143, 206-213.

BERT. P. Barometric pressure; Researches in experimental physiology. (Translated by M. A. Hitchcock and F. A. Hitch cock) Columbus: College Book, 1943.

CHOROVER, S. L., \& SCHILLER, P. H Short-term retrograde amnesia in rats. Journal of Comparative \& Physiological Psychology, 1965, 59, 73-78.

DICKENS, F. The toxic effects of oxygen on brain metabolism. Journal of Biochemistry, 1946,40,145-158.

HAUGAARD, N. Cellular mechanisms of oxygen toxicity. Physiological Review. $1968,48,311-374$

JOHNSON, D. C.. \& BEAN, J. W. Effect of sympathetic blocking agents on the toxic action of OHP. American Journal of Physiology, 1957, 188, 593-598.

LASHLEY, K, Brain mechanisms and intelligence. New York: Hafner, 1964.

McGAUGH, J. L., \& PETRINOVITCH, F. L. Effects of drugs on learning and memory. International Review of Neurobiology, 1965, 8, 139-196.

TAYLOR, D. W. The effect of vitamin $E$ and methylene blue on the manifestations of oxygen poisoning in the rat. Journal of Physiology, 1956, 131, 200-206.

WOOD, J. D., WATSON, W. J., \& CLYDESDALE, F. M. GABA and oxygen poisoning. Journal of Neurochemistry, $1967,14,1067-1074$.
Table 2

The Effects of OHP Upon the Retention of the T-Maze Habit in Rats

\begin{tabular}{|c|c|c|c|c|c|}
\hline $\begin{array}{c}\text { Animal } \\
\text { Number } \\
\text { and Group }\end{array}$ & $\begin{array}{l}\text { Errors to } \\
\text { Criterion }\end{array}$ & $\begin{array}{l}\text { Trials to } \\
\text { Criterion }\end{array}$ & & $\begin{array}{l}\text { Errors to } \\
\text { Criterion }\end{array}$ & $\begin{array}{l}\text { Trials to } \\
\text { Criterion }\end{array}$ \\
\hline \multicolumn{6}{|l|}{ Experimental } \\
\hline B1 & 22 & 63 & OHP & 1 & 11 \\
\hline B5 & 17 & 50 & & 3 & 25 \\
\hline B7 & 26 & 66 & & 2 & 12 \\
\hline B3 & 29 & 81 & & 1 & 11 \\
\hline Mean & 23 & 65 & & 1.7 & 14.7 \\
\hline \multicolumn{6}{|l|}{ Control } \\
\hline B4 & 14 & 53 & 10 Days & 2 & 12 \\
\hline B8 & 16 & 51 & & 0 & 10 \\
\hline B 2 & 34 & 85 & & 3 & 15 \\
\hline B 6 & 32 & 100 & & 1 & 11 \\
\hline Mean & 24 & 72.2 & & 1.5 & 12 \\
\hline
\end{tabular}

